\title{
Acceptance of illness by women with breast cancer
}

\author{
Elżbieta Cipora', Magdalena Konieczny'1, Jarosław Sobieszczański² \\ ${ }^{1}$ Medical Institute, Jan Grodek State Higher Vocational School, Sanok, Poland \\ ${ }^{2}$ Chair and Department of Conservative Dentistry with Endodontic, Medical University, Lublin, Poland \\ Cipora E, Konieczny M, Sobieszczański J. Acceptance of illness by women with breast cancer. Ann Agric Environ Med. $2018 ; 25(1)$ : 167-171. \\ doi: 10.26444 /aaem/75876
}

\section{Abstract}

Introduction. Despite great progress in the diagnostics and treatment, breast cancer still remains the most frequently diagnosed malignant cancer in women. The outcomes of cancer treatment depend, to a considerable extent, on the degree of acceptance of the illness. The objective of the study was determination of the level of acceptance of the disease among the examined women with breast cancer.

Materials and method. The study covered a group of 231 women who received treatment for breast cancer in the Rev. Bronislaw Markiewicz Subcarpathian Oncology Centre in Brzozow, south-eastern Poland, and conducted by the method of a diagnostic survey, using an author constructed questionnaire and the standard Acceptance of IIIness Scale, adapted by Z. Juczyński. Statistical analyses were performed using the software IBM SPSS v. 21.0.0.1. The $p$ values $p \leq 0.05$ were considered statistically significant.

Results. The mean level of acceptance of the illness in the examined group of women was $26.53(\mathrm{SD}=7.71 ; \mathrm{Me}=26)$. The largest number of respondents (50.6\%) obtained scores within the range of 20-29, according to the AIS Scale. From among the adopted variables, the level of acceptance of the illness significantly varied according to age and occupational activity. However, no such differences were confirmed according to the place of residence, marital status, education level, or the type of occupation performed.

Conclusions. In the examined group of women, a mediocre level of acceptance of cancer was observed. The respondents' age and occupational situation exerted a significant effect on the level of acceptance of the illness. The results of the study should be considered as satisfactory because the number of women with a high level of acceptance of breast cancer was more than twice as high as those ones with a low acceptance of the disease.

\section{Key words}

breast cancer, demographic factors, AIS Scale, acceptance of illness

\section{INTRODUCTION}

Malignant cancer is one of the main health and social problems of contemporary populations [1]. In Poland, it occupies the second position among the causes of death and, according to the epidemiological prognoses, morbidity due to malignant cancer will systematically increase. Breast cancer is one of the malignancies which are most frequently diagnosed in women. In the population of Polish women it is also the most frequent cause of death due to cancer $[2,3]$.

Diagnosis of breast cancer disturbs the functioning of many, if not all, women in almost every sphere of life [4, 5]. The psychological sphere is one of the most important because, apart from the ill person, also people who are the closest experience various types of negative emotions, such as fear, anger, the feeling of threat, helplessness and uncertainty $[6,7]$. Some researchers emphasize the importance of the patient's attitude towards the disease and the skills of coping with emotions resulting from the health situation $[8,9]$.

Each woman diagnosed with breast cancer requires a longlasting and complex process of treatment, rehabilitation and care. The type of care should be directed towards support in major problems, the recognition of which requires individual identification. The quickest possible acceptance of the disease by a woman ill with cancer is of great importance in widely

Address for correspondence: Elżbieta Cipora, Medical Institute, Jan Grodek State Higher Vocational School, Sanok, Poland

e-mail: elacipora@interia.pl

Received: 29 March 2017; accepted: 19 May 2017; first published on July, 102017 understood therapy [10]. This results in a positive attitude towards treatment, and increases the skills of living with the illness. Acceptance of illness is coming to terms with own state of health, it enables the actual assessment of one's own health situation, and often provides incentives to struggle against the disease $[11,12,13,14]$.

Due to the variety of problems occurring in breast cancer, a woman requires support from the closest family members and various specialists, mainly a psychologist. Many studies show that the higher the level of support in cancer, the easier the ill person accepts own situation $[6,9,13,15]$.

\section{OBJECTIVE}

The objective of the study was determination of the level of acceptance of illness by women treated for breast cancer.

\section{MATERIALS AND METHOD}

The study was conducted in a group of 231 women treated for breast cancer at the Rev. Bronislaw Markiewicz Subcarpathian Oncology Centre in Brzozow, south-eastern Poland, from February 2015 - October 2016. Respondents' mean age $-56.23(\mathrm{SD}=10.94)$; the youngest was aged 30 , and the oldest -80 .

The sample for the study was selected by purposive sampling. Inclusion criteria were: diagnosed and documented 
disease - breast cancer, maintaining a logical contact, and obtaining patient's consent to participate in the study. Consent for the study was obtained from the Bioethical Committee at the Jan Grodek State Higher Vocational School in Sanok and the Director of the Subcarpathian Oncology Centre in Brzozów. Prior to the study, all respondents were informed concerning its objective, were assured anonymity, voluntariness of participation, and the right to withdraw from the study at any stage.

The study was conducted by the method of a diagnostic survey. Data was collected using 2 research instruments. The first instrument was a questionnaire designed by the author, which contains 32 items arranged in 6 problem groups. For the purpose of the presented study, only one part of the instrument was used, i.e. demographic and social data. The second instrument was the standard Acceptance of Illness Scale (AIS) by B. J. Felton, T. A. Revenson and G. A. Hinrichen, adopted by Z. Juczyński [16]. This scale consists of statements allowing assessment of the level of acceptance of the illness by the examined person. The statements handle negative consequences of the disease, which result in problems with adjustment to the limitations related with the disease, sense of the lack of self-sufficiency and usefulness, dependence on others, and lower self-esteem. Due to this, a patient may feel a burden on the closest persons. Assessment of acceptance of the illness is performed based on a 5-degree scale, i.e. 1 - I definitely agree, 2 - I agree, 3 - I do not know, 4 - I do not agree, 5 - I definitely do not agree. The level of acceptance of the disease is measured by summing-up scores from individual statements. The overall scope of acceptance remains within the range $8-40$. The higher the result obtained, the higher the level of acceptance of the illness.

The results obtained were statistically analyzed using the software IBM SPSS v. 21.0.0.1. Quantitative variables were investigated using analysis of variance (ANOVA). In order to characterize these variables, the minimum and maximum value, arithmetic mean, and standard deviation were presented. The correlations between variables were assessed using Pearson correlation coefficient. The $p$ values $\mathrm{p} \leq 0.05$ were considered statistically significant.

\section{RESULTS}

More than a half of the respondents were rural inhabitants (50.2\%), and the reminder lived in cities $(49.8 \%)$ - population up to $20,000-23.8 \%$, population from $21,000-50,000-$ $18.6 \%$, more than $50,000-7.4 \%$. The majority of the examined women were married $-71.0 \%$. The largest number of respondents had secondary school education (44.6\%), nearly one-fourth possessed university education (23.8\%), one-fifth - primary vocational education (20.3\%), and $11.3 \%$ of the women reported primary education. The type of occupation performed was determined by the ranking method. The largest group were respondents qualified into the group of specialists (26\%), a slightly smaller group included women classified into the group of technicians and other medium-level staff $(23.8 \%)$. Employees of services and sales staff constituted $12.5 \%$, while slightly less women $11.2 \%$, were classified into the group of industrial workers and craftsmen. Workers who performed simple jobs constituted $6.1 \%$, office workers $-4.8 \%$, and farmers $-3.9 \%$. The lack of learned profession concerned $11.7 \%$ of the women in the study. For the majority of respondents (54.5\%), the source of maintenance was retirement pension, disability allowance, or the income of persons living in the same household. The remaining women, i.e. $45.5 \%$, maintained themselves on occupational activity performed.

The mean value of the overall indicator of acceptance of illness in the examined group was 26.53, with standard deviation 7.71 , and median 26 . This value means a mediocre level of acceptance of the disease by the women in the study. A half of the respondents (50.6\%) obtained the number of scores within the range $20-29$, i.e. the values which indicate a mediocre level of acceptance of the illness. The second group were women who obtained 30-40 scores, which evidences a high level of acceptance of the disease. The lowest number of scores (8-19) was obtained by $15.2 \%$ of the total number of respondents, which is synonymous with a low level of acceptance of the illness (Tab. 1).

Table 1. Level of acceptance of illness according to the AIS Scale in the examined group of women

\begin{tabular}{lccc}
\hline Intervals acc. to AIS Scale & Scores & $\mathrm{N}$ & $\%$ \\
\hline Low & $8-19$ & 35 & 15.2 \\
\hline Mediocre & $20-29$ & 117 & 50.6 \\
\hline High & $30-40$ & 79 & 34.2 \\
\hline Total & 26.53 & 231 & 100 \\
\hline
\end{tabular}

The mean values of the level of acceptance of the disease in individual statements of the Scale were similar, with the highest result (3.41) obtained in category 6: Due to my health status I do not feel a fully valued human being, and the lowest (3.16) concerning the first statement: I have problems with adjustment to the limitations imposed by the illness. Table 2 presents the results obtained in the remaining categories.

Table 2. Statistics of the AIS Scale and its components

\begin{tabular}{|c|c|c|c|c|c|c|}
\hline \multirow[t]{2}{*}{ AIS Scale } & Mean & $\begin{array}{l}\text { Standard } \\
\text { deviation }\end{array}$ & $\begin{array}{l}\text { Mini- } \\
\text { mum }\end{array}$ & $\begin{array}{l}\text { Maxi- } \\
\text { mum }\end{array}$ & Median & $\mathrm{N}$ \\
\hline & 26.53 & 7.71 & 8 & 40 & 26 & 231 \\
\hline $\begin{array}{l}\text { 1. I have problems with } \\
\text { adjustment to the limitations } \\
\text { imposed by the illness }\end{array}$ & 3.16 & 1.28 & 1 & 5 & 3 & 231 \\
\hline $\begin{array}{l}\text { 2. Due to my state of health I } \\
\text { am not able to do what I like } \\
\text { best }\end{array}$ & 3.24 & 1.29 & 1 & 5 & 3 & 231 \\
\hline $\begin{array}{l}\text { 3. The disease sometimes } \\
\text { makes me feel unnecessary }\end{array}$ & 3.33 & 1.38 & 1 & 5 & 3 & 231 \\
\hline $\begin{array}{l}\text { 4. Because of health problems I } \\
\text { am more dependent on others } \\
\text { than I wish to be }\end{array}$ & 3.34 & 1.31 & 1 & 5 & 3 & 231 \\
\hline $\begin{array}{l}\text { 5. Due to the disease I am } \\
\text { a burden on my family and } \\
\text { friends }\end{array}$ & 3.37 & 1.42 & 1 & 5 & 3 & 231 \\
\hline $\begin{array}{l}\text { 6. Due to my health status I do } \\
\text { not feel a fully valued human } \\
\text { being }\end{array}$ & 3.41 & 1.37 & 1 & 5 & 4 & 231 \\
\hline $\begin{array}{l}\text { 7. I will never be self-sufficient } \\
\text { to the degree I would like to be }\end{array}$ & 3.37 & 1.28 & 1 & 5 & 3 & 231 \\
\hline $\begin{array}{l}8 . \text { I think that people who stay } \\
\text { with me are often embarrassed } \\
\text { because of my illness }\end{array}$ & 3.31 & 1.26 & 1 & 5 & 3 & 231 \\
\hline
\end{tabular}


Relationships were assessed between the demographic factors selected for analyses, i.e. age, place of residence, marital status, education level, occupation performed and source of maintenance, and the level of acceptance of breast cancer by the examined women.

Table 3. AIS Scale and respondents' age

\begin{tabular}{lcccccc}
\hline & \multicolumn{6}{c}{ Age intervals } \\
\cline { 2 - 7 } & Total & $30-39$ & $40-49$ & $50-59$ & $60-69$ & $70+$ \\
\hline AIS Scale & 26.53 & 29.37 & 28.41 & 25.80 & 25.49 & 25.04 \\
\hline
\end{tabular}

$r$ Pearson $=-0.155 ; p=0.018$

Age negatively correlated with the mean values obtained according to the AIS Scale. The older the age category of the examined women, the lower the mean value of acceptance of the illness. Clearly higher mean values of acceptance of the illness were observed in the subpopulations of women in the first (30-39-29.37) and the second age group (40-49 - 28.41), compared to the reminder, where the mean values were as follows: $50-59-25.80 ; 60-69-25.49 ; 70$ and over -25.04 .

No statistically significant differences in the level of acceptance of cancer were confirmed according to the place of residence of the examined women ( $\mathrm{p}=0.978)$. However, it should be noted that urban inhabitants obtained a slightly higher level of acceptance of the illness than women living in rural areas (Tab. 4).

Table 4. AIS Scale and respondents' place of residence

\begin{tabular}{lccccccc}
\hline & \multicolumn{5}{c}{ AlS Scale } \\
\cline { 2 - 7 } Place of residence & Mean & $\begin{array}{l}\text { Standard } \\
\text { deviation }\end{array}$ & $\begin{array}{c}\text { Mini- } \\
\text { mum }\end{array}$ & $\begin{array}{c}\text { Maxi- } \\
\text { mum }\end{array}$ & Median & N \\
\hline Rural area & 26.32 & 7.10 & 8 & 40 & 26 & 116 \\
\hline $\begin{array}{l}\text { City with population up to } \\
20,000\end{array}$ & 26.84 & 6.52 & 8 & 38 & 26 & 55 \\
\hline $\begin{array}{l}\text { City with population from } \\
21,000-50,000\end{array}$ & 26.58 & 9.75 & 9 & 40 & 27 & 43 \\
\hline $\begin{array}{l}\text { City with population over } \\
50,000\end{array}$ & 26.82 & 9.96 & 10 & 40 & 24 & 17 \\
\hline Total & 26.53 & 7.71 & 8 & 40 & 26 & 231 \\
\hline
\end{tabular}

Respondents who were married or lived in a consensual relationship showed a higher level of acceptance of the disease than women in other categories of marital status; however, the difference was statistically insignificant $(\mathrm{p}=0.465)$ (Tab. 5).

Table 5. AIS Scale and marital status of women in the study

\begin{tabular}{lccccccc}
\hline & \multicolumn{6}{c}{ AlS Scale } \\
\cline { 2 - 7 } Marital status & Mean & $\begin{array}{l}\text { Standard } \\
\text { deviation }\end{array}$ & $\begin{array}{c}\text { Mini- } \\
\text { mum }\end{array}$ & $\begin{array}{c}\text { Maxi- } \\
\text { mum }\end{array}$ & Median & N \\
\hline $\begin{array}{l}\text { Married/consensual } \\
\text { relationship }\end{array}$ & 26.76 & 7.75 & 8 & 40 & 26 & 168 \\
\hline Other & 25.92 & 7.66 & 9 & 40 & 25 & 63 \\
\hline Total & $\mathbf{2 6 . 5 3}$ & $\mathbf{7 . 7 1}$ & $\mathbf{8}$ & $\mathbf{4 0}$ & $\mathbf{2 6}$ & $\mathbf{2 3 1}$ \\
\hline
\end{tabular}

Data concerning the level of education showed that the women who reported university education achieved a higher level of acceptance of the illness, compared to the respondents in each of the lower categories of education (28.65). The mean values according to the AIS Scale did not significantly differ $(\mathrm{p}=0.120)($ Tab. 6).

Table 6. AIS Scale and education level of the examined women

\begin{tabular}{lccccccc}
\hline & \multicolumn{6}{c}{ AlS Scale } \\
\cline { 2 - 7 } Education & Mean & $\begin{array}{c}\text { Standard } \\
\text { deviation }\end{array}$ & $\begin{array}{c}\text { Mini- } \\
\text { mum }\end{array}$ & $\begin{array}{c}\text { Maxi- } \\
\text { mum }\end{array}$ & Median & N \\
\hline Primary & 26.65 & 7.27 & 9 & 38 & 26 & 26 \\
\hline Primary vocational & 25.62 & 6.62 & 11 & 40 & 25 & 47 \\
\hline $\begin{array}{l}\text { Secondary school/upper- } \\
\text { secondary (general, vocational, } \\
\text { including post-secondary) }\end{array}$ & 25.78 & 7.64 & 8 & 40 & 25 & 103 \\
\hline University, including licentiate & 28.65 & 8.65 & 8 & 40 & 30 & 55 \\
\hline Total & 26.53 & 7.71 & 8 & 40 & 26 & 231 \\
\hline $\mathrm{p}=0.120$ & & & & & &
\end{tabular}

Occupation performed was also a characteristics which did not show any significant differences with respect to the acceptance of the disease in the examined group of women $(\mathrm{p}=0,786)$. Despite this, it should be emphasized that the lowest mean value according to the AIS Scale (23.91) was observed among office workers, and the highest - in the group of specialists (27.82). It is noteworthy that women who did not have any learned profession occupied the second position with respect to the mean value (27.07) (Tab.7).

Table 7. AIS Scale and learned profession

\begin{tabular}{|c|c|c|c|c|c|c|}
\hline \multirow[b]{2}{*}{ Learned profession } & \multicolumn{6}{|c|}{ AIS Scale } \\
\hline & Mean & $\begin{array}{l}\text { Standard } \\
\text { deviation }\end{array}$ & $\begin{array}{l}\text { Mini- } \\
\text { mum }\end{array}$ & $\begin{array}{l}\text { Maxi- } \\
\text { mum }\end{array}$ & Median & $\mathrm{N}$ \\
\hline Specialists & 27.82 & 8.41 & 8 & 40 & 29 & 60 \\
\hline $\begin{array}{l}\text { Technicians and other } \\
\text { medium-level staff }\end{array}$ & 26.27 & 8.50 & 8 & 40 & 26 & 55 \\
\hline Office workers & 23.91 & 7.35 & 14 & 39 & 24 & 11 \\
\hline $\begin{array}{l}\text { Employees of services and } \\
\text { sales staff }\end{array}$ & 25.90 & 7.49 & 11 & 40 & 24 & 29 \\
\hline $\begin{array}{l}\text { Farmers, horticulturists, } \\
\text { forestry workers and fishermen }\end{array}$ & 24.89 & 6.33 & 18 & 40 & 24 & 9 \\
\hline $\begin{array}{l}\text { Industrial workers and } \\
\text { craftsmen }\end{array}$ & 26.46 & 7.45 & 9 & 39 & 27 & 26 \\
\hline $\begin{array}{l}\text { Employees performing simple } \\
\text { jobs }\end{array}$ & 25.50 & 6.27 & 11 & 37 & 26 & 14 \\
\hline Without profession & 27.07 & 6.32 & 15 & 38 & 27 & 27 \\
\hline Total & 26.53 & 7.71 & 8 & 40 & 26 & 231 \\
\hline
\end{tabular}

$p=0.786$

Significant differences in the level of acceptance of the disease $(p=0.005)$ were found between the group of respondents who were occupationally active, and those who maintained themselves on a retirement pension or other non-earned sources of maintenance. Women who were occupationally active more often accepted their illness (28.10), than those occupationally non-active (25.22) (Tab. 8). 
Table 8. AIS Scale and source of maintenance of the examined women

\begin{tabular}{lccccccc}
\hline & \multicolumn{6}{c}{ AlS Scale } \\
\cline { 2 - 7 } Source of maintenance & Mean & $\begin{array}{l}\text { Standard } \\
\text { deviation }\end{array}$ & $\begin{array}{c}\text { Mini- } \\
\text { mum }\end{array}$ & $\begin{array}{l}\text { Maxi- } \\
\text { mum }\end{array}$ & Median & N \\
\hline $\begin{array}{l}\text { Retirement pension, health } \\
\begin{array}{l}\text { allowance, non-earned sources } \\
\text { of maintenance }\end{array}\end{array}$ & 25.22 & 7.86 & 8 & 40 & 24 & 126 \\
\hline Work & 28.10 & 7.27 & 10 & 40 & 28 & 105 \\
\hline Total & $\mathbf{2 6 . 5 3}$ & $\mathbf{7 . 7 1}$ & $\mathbf{8}$ & $\mathbf{4 0}$ & $\mathbf{2 6}$ & $\mathbf{2 3 1}$ \\
\hline
\end{tabular}

$p=0.005$

\section{DISCUSSION}

The only factor which exerts an effect on the quality of life of the patients with breast cancer is acceptance of the illness, which enables an objective evaluation of own state of health and motivates the patient for coping with the disease [10, 17]. In own study, the mean value of the overall indicator of acceptance of cancer among the examined women was 26.53 . Similar results were obtained by Lewandowska-Abucewicz et al., where the mean value according to the AIS Scale was 26.8 [18]. In the study by Łuczyk et al., in the group of women who received surgical treatment due to breast cancer, a mediocre level of acceptance of the disease was observed [12]. The overall result according to the AIS Scale in this group was 25.82 scores. In the study by Kamińska et al., the highest level of acceptance of breast cancer was noted among women who had undergone radical mastectomy and adjuvant hormonal therapy. However, the lowest level of acceptance of the disease was found in women who had undergone breastconserving surgery and chemotherapy [19]. In the study conducted by Ślusarska et al., the level of acceptance of the disease in patients with cancer of the lymphatic system was 20.61. A considerable difference was confirmed in the mean level of acceptance of the disease between women with breast cancer and those with lymphomas [20]. It may be presumed that the level of acceptance of the disease may be related with the type of cancer. Similar results were obtained in the study by Religioni et al. conducted among patients with lung, prostate, and colorectal cancer. The level of acceptance of the illness in these patients depended on the type of cancer, and was the highest in patients with prostate cancer (30.39), while the lowest in patients with lung cancer (23.17). Among women with breast cancer, the level of acceptance according to the AIS Scale was 28.46. In addition, a linear relationship was observed between income per household member and the result according to the AIS Scale. The higher the income, the higher the level of acceptance of the disease according to the AIS Scale [21].

In own study, it was found that the highest percentage of women (50.6\%) accepted their disease on the mediocre level. Slightly less women $-34.2 \%$, obtained a high level of acceptance of the disease, whereas a low level of acceptance of the disease concerned $15.2 \%$ of respondents. In their study, Łuczyk et al., similar to the study by Pawlik and Kaczmarek-Borowska, the largest groups of women (39.43\% and $46.29 \%$, respectively) obtained a high level of acceptance of the disease, whereas, similar to own study, the lowest level concerned the smallest group of respondents $[12,11]$.

The study showed that age negatively correlated with the mean values obtained according to the AIS Scale, i.e. the younger the woman, the higher the level of acceptance of the disease. The highest value according to the AIS Scale -29.37 was obtained by women in the youngest age group - 30-39, while the lowest - 25.04, those aged 70 and over. Different results were obtained by Pawlik and KaczmarekBorowska, which showed that age, education level, and place of residence had no effect on the level of acceptance of breast cancer in women after mastectomy [11]. In more than a half of the women in the study, cancer and mastectomy did not result in a decrease in their self-esteem. The examined women considered themselves as fully valuable and needed. Studies conducted among Polish women who had undergone mastectomy indicated that more than $75 \%$ of respondents accepted the cancer disease [11]. In the study by Łuczyk et al., younger women obtained a slightly higher level of acceptance of the disease, compared to those who were older - 26.04 vs. 25.68 ; however, this difference was statistically insignificant [12].

In own study, a slightly higher level of acceptance of the disease was obtained by urban inhabitants, compared to those living in rural areas, but the differences were not significant statistically. The study by Kupcewicz and Abramowicz showed that the level of acceptance of the disease by patients with chronic obstructive pulmonary disease was determined by the respondents' gender, age, and socio-economic status; whereas the level of education and place of residence exerted no effect on the level of acceptance of the disease [22].

Support of people from the nearest surroundings and support provided by nurses, physicians, and other health care professionals is of great importance in the course of cancerous disease [23]. Own study showed that married women and those living in consensual union had a higher level of acceptance of the disease than women in the remaining categories of marital status. The p value obtained did not indicate a statistically significant relationship. The study by Łuczyk et al. demonstrated an opposite situation, i.e. married persons had a lower level of acceptance of the disease, compared to those single (25.35 vs. 26.78) [12].

In own study, the highest mean value concerning acceptance of the illness was obtained by women who had university education (28.65), while the lowest level was noted in women who reported primary vocational education (25.62). Similarly, in the study by Pawlik and KaczmarekBorowska, the highest mean value according to the AIS Scale was obtained by women with university education (29.12), whereas the lowest value - among those with vocational education (24.71) [11]. In the study by Łuczyk et al., a statistically significant relationship was confirmed between acceptance of the disease and education level. The highest values of acceptance of the disease were observed in the group of women who had primary and university education [12].

In own study, it was observed that occupationally active women obtained a higher level of acceptance of the disease (28.10), compared to those who were non-active occupationally (25.22). The differences in the mean values between these two groups were statistically significant $(\mathrm{p}=$ 0.005). In the study conducted by Czerw et al. in a group of 193 patients with breast cancer, it was found that the level of acceptance of the disease depended on the respondents' material standard. The higher the respondents' income, the higher the level of acceptance of the disease [15]. Similar results were discovered in the study by Chen et al. [24]. In another study, Czerw et al. confirmed that the mean level of 
acceptance of the disease by patients with prostate cancer was 30.39. In this group of respondents some socio-economic factors were important. This relationship concerned the level of education and the amount of income. The lowest level of acceptance of the disease was observed among respondents who declared primary education; whereas the highest level - in patients who had secondary school and university education. Here, a linear relationship was confirmed between an increase in income per household member and a higher level of acceptance of the disease. The remaining socioeconomic factors, including occupational status and place of residence exerted no significant effect on the level of acceptance of the disease by the examined women [25].

The results of own study and studies by other researchers show that patients with a lower social status require greater support in order to obtain the highest possible level of acceptance of cancerous disease $[15,25,26]$.

\section{CONCLUSIONS}

1. In the majority of the examined women, mean values were obtained on the level of 26.53 , which indicates a mediocre level of acceptance of the disease in the examined population of women.

2. The level of acceptance of cancer depended on the respondents' age and their occupational situation. Younger women obtained a higher level of acceptance of their illness, compared to those who were older. It was confirmed that occupational activity was an important factor in obtaining higher values according to the AIS Scale by the women in the study.

3. Such demographic characteristics as the place of residence, marital status, education level, and type of the occupation performed had no significant effect on the level of acceptance of the cancer.

4. The results of the study from the socio-medical point of view should be considered as satisfactory, because the number of women with the high level of acceptance of breast cancer was more than twice as high as those with a low acceptance of the disease.

\section{REFERENCES}

1. Stewart B, Wild CP. (eds.). International Agency for Research on Cancer, WHO. (2014). World Cancer Report 2014 [Online]. Available from: http://www.thehealthwell.info/node/725845 [Accessed: 18th March 2017].

2. Rapport International Agency Research Cancer "GLOBOCAN 2012".

3. Główny Urząd Statystyczny (Central Statistical Office) (2014). Warsaw: Basic facts regarding Polish demographics in 2011. Available from: http://www.stat.gov.pl/cps/rde/xbcr/gus/l_podst_inf__o__syt_ demograficznej_2011.pdf. Polish (access: 2016.11.10).

4. Gall TL, Bilodeau C. "Why me?" - women's use of spiritual causal attributions in making sense of breast cancer. Psychol Health. 2017; 32: 709-727. doi: 10.1080/08870446.2017.1293270.

5. Buki LP, Reich M, Lehardy EN. "Our organs have a purpose": body image acceptance in Latina breast cancer survivors. Psycho-Oncology, 2017; 25: 1337-1342. doi: 10.1002/pon.4270.
6. Wojtyna E, Życińska J, Stawiarska P. The influence of cognitivebehaviour therapy on quality of life and self-esteem in women suffering from breast cancer. Rep Pract Oncol Radiother. 2007; 12(2): 109-117.

7. Vrinten C, McGregor LM, Heinrich M, von Wagner C, Waller J, Wardle J, Black GB. What do people fear about cancer? A systematic review and meta-synthesis of cancer fears in the general population. 2016; Psycho-Oncology, doi: 10.1002/pon.4287.

8. Petrie KJ, Jago LA, Devcich DA. The role of illness perceptions in patients with medical conditions. Curr Opin Psychiatr. 2007; 20: $163-167$.

9. Linton SJ, Shaw WS. Impact of psychological factors in the experience of pain. Physical Therapy. 2011; 91: 700-711.

10. Al-Azri M, Al-Awisi H, Al-Moundhri M. Coping With a Diagnosis of Breast Cancer-Literature Review and Implications for Developing Countries. Breast J. 2009; 15: 615-622. doi:10.1111/j.15244741.2009.00812.x.

11. Pawlik M, Kaczmarek-Borowska B. Akceptacja choroby nowotworowej u kobiet po mastektomii. Prz. Med. Uniw. Rzesz Nar. Inst. Lek. w W-wie. 2013; 2: 203-211.

12. Łuczyk M, Pietraszek A, Łuczyk R, Stanisławek A, SzadowskaSzlachetka Z, Charzyńska-Gula M. Akceptacja choroby w grupie kobiet leczonych chirurgicznie z powodu nowotworu piersi (Illness acceptance among women who have undergone surgical treatment for a breast neoplasm). J Edu. Health and Sport. 2015; 5(9): 569-575.

13. Lueboonthavatchai P. Prevalence and psychosocial factors of anxiety and depression in breast cancer patients. J Med Assoc Thai. 2007; 90(10): 2164-2174.

14. Pinto B, Trunzo J, Reiss P, Shiu S-Y. Exercise participation after diagnosis of breast cancer: trends and effects on mood and quality of life. Psychooncology. 2002; 11: 398-400.

15. Czerw A, Religioni U, Deptała A. Assessment of pain, acceptance of illness, adjustment to life with cancer and coping strategies in breast cancer patients. Breast Cancer. 2016; 23(4): 654-661.

16. Juczyński Z. Narzędzia pomiaru w promocji i psychologii zdrowia. Pracownia Testów Psychologicznych Polskiego Towarzystwa Psychologicznego. Warszawa 2001.

17. Joly F, Espie M, Marty M. Long-term quality of life in premenopausal women with node-negative localized breast cancer treated with or without adjuvant chemotherapy. Br J Cancer. 2000; 83(5): 577-582.

18. Lewandowska-Abucewicz T, Kęcka K, Brodowski J. Akceptacja choroby nowotworowej u kobiet po mastektomii w województwie zachodniopomorskim - badania wstępne. Fam Med Prim Care Rev. 2016; 18(2): 143-148.

19. Kamińska M, Ciszewski T, Bronikowska A, Ferańska M, PawlakWarszawska A, Paśnik E. Acceptance of the illness and the quality of life of patients with breast cancer. Zdr Publ. 2014; 124(1): 5-9.

20. Ślusarska B, Nowicki GJ, Serwata M, Zboina B, Łuczyk M, SzadowskaSzlachetka Z. Poziom akceptacji choroby i jakość życia chorych na chłoniaki. Med Pal. 2016; 8(2): 88-95.

21. Religioni U, Czerw A, Deptała A. Acceptance of cancer in patients diagnosed with lung, breast, colorectal and prostate carcinoma. Iran J Public Health. 2015; 44(8): 1135-1142.

22. Kupcewicz E, Abramowicz A. Wpływ wybranych czynników socjodemograficznych na stopień akceptacji choroby i poziom satysfakcji z życia u pacjentów leczonych z powodu przewlekłej obturacyjnej choroby płuc (Influence of selected socio-demographic factors on degree of illness acceptance and on level of satisfaction with life in patients with chronic obstructive pulmonary disease). Hygeia Public Health. 2015; 50(1): 142-148.

23. Mermer G, Nazli A, Ceber E, Mermer G. Social perceptions of breast cancer by women still undergoing or having completed therapy: a qualitative study. Asian Pac J Cancer Prev. 2016; 17(2): 503-510.

24. Chen S-Q, Liu J-E, Zhang Z-X, Li Z. (2017), Self-acceptance and associated factors among Chinese women with breast cancer. J Clin Nurs. 2017; doi:10.1111/jocn.13437

25. Czerw AI, Religioni U, Deptała A, Fronczak A. Pain, acceptance of illness, adjustment to life with cancer and coping strategies in prostate cancer patients. Arch Med Sci. 2016; DOI: doi.org/10.5114/ aoms.2016.58458.

26. Manuel JC, Burwell SR, Crawford SL, Lawrence RH, Farmer DF, Hege A, Phillips K, Avis NE. Younger women's perceptions of coping with breast cancer. Cancer Nurs. 2007; 30(2): 85-94. 